\title{
The Character Education in Learning Mathematics at Elementary School
}

\author{
Desti Rahayu, Sutama, Sabar Narimo, Achmad Fathoni \\ Masters in Basic Education \\ Universitas Muhammadiyah Surakarta
}

\begin{abstract}
Integration of character education in elementary schools is a movement to strengthen character education in shaping and developing student character. This research is a qualitative study that use normative qualitative descriptive approach. The data was collecting by doing interview, observation and study documentation. The result showed that the implementation of education in learning mathematics can be realized based on the target that want to be achieved by the researcher. The character education that was built through this learning was the values that taught based on the subject such as discipline, responsibility and teamwork. The character building was realized by integrating the character values in learning mathematics to make students able to implement the values in daily life. The integration was executed by combining the character values that exist in lesson plan and the students' consistency in implementing these values outside the school. In measuring the result, the teacher gave the assessment book to the students.
\end{abstract}

Keywords:- Character, Mathematics, Elementary School.

\section{INTRODUCTION}

Education is a foundation that really important for a country. In Indonesia the plan to increase the social life has already explained in the opening of constitution (UUD 1945), fourth paragraph "the government organize the education program that was formulated as a system of national education. The purpose of national education was stated in a regulation number 20 in 2003 article 3 . Education in this regulation can be interpreted as an effort to build the character of a nation. This character can be the identity of a nation, so cannot be followed by others. In this case, the character education will give big impact for the students' attitude.

Indonesia is currently experiencing a moral crisis such as crime that is happening everywhere. Ironically, the perpetrators are not only from the adults but also children. Today, the students do not have respect to the teacher, even when the teacher try to warning them, they make a report to the police to arrest the teacher. This situation get attention from the teacher, and make them worried to help the students in building their character because they wouldn't take a risk. This moral crisis happened because there is no harmonization between the intellectuality and the moral value (Suryadi,
2012:96), so the character education can be the right solution to solve the problem.

The character education can be implemented to build the good habit and need to trained since the very beginning. So, the government try to socialized the program of character education to help the teacher taking care the moral crisis of their students to minimized their bad attitude that can harm the other people. The kinds of character education that should be established students personality like religious, nationalist, independent, integrity, teamwork, responsibility, integrity, creative, awareness, friendly, discipline and many others. These values are needed to applied to the students since the very beginning. We can start from the elementary school which the basic foundation to spread over the values and also we need the commitment to implement it in learning process.

According to Ariyanti L (2017), the character education is a system that can be a tool to spread over the moral values in a school that consist of knowledge, awareness and action to implement those values to a better person. The character education can be applied in every subject like science, social and mathematic. Especially in mathematics, the teacher can socialize some character education that can help the students to be tough and accurate. Nowadays, the curriculum is already focus to increase the quality of learning process to more effective, efficient and fun. Through this kinds of learning process, the student can find the concept, solving the problem and implement the values in daily life.

The process in building student's character can be executed by making some policies that had been socialized well to the teacher. The teacher has the important role in teaching moral values and building students' independence. In supporting the character education, mathematic can be applied by integrating the subject and the character that exist in the topic. So, the teacher should be more innovative in teaching the character education in every subject so the students can implement it in their daily life.

The implementation of character values to the students is able to develop their own positive character. In addition, the implementation of the character values in each subject is like a support from the teacher to the government that already make the PKK (an action to provision the character education). Character is a basic value that builds a person's personality, so it will be formed well because of environmental influences. In response to this the school has a very important role in shaping the character of students 


\section{METHOD}

This is qualitative research which means the data was collected systematically and logic to reach the purpose of the research (Sutama, 2016:25). This research also used normative qualitative descriptive approach in analyzing students' activity through the learning process that focus on the implementation of character values in mathematic subject at SD Negeri 2 Sukorejo, Klaten, Central Java.

The data collected by doing observation, interview and study documentation. In doing observation the researcher only perceives the subject (a non-participant). The interview has already designed by the researcher like preparing the questions first to make it easier and about the study documentation, the researcher collects the data from the school's document that has correlation with this research. Generally, the data analysis was executed by doing interactive model (Miles, Huberman \& Saldana, 2014) that use three steps like data reduction, data presentation and verification.

\section{RESEARCH RESULT}

The research was conducted at SD Negeri 2 Sukorejo and the researcher found some problems and also strategy in implementing the character education in teaching mathematic by the teacher. The result shows that the character education consists of some element like the coordination between the teacher and the school to support the implementation of character education in learning mathematic. The implementation of character education was integrated through the lesson plan in all subject. This integration process is aimed to build the students' character in lesson plan. The character building was realized by identifying the subject matter to be integrated by the character values that fit in the topic. The character values were related to the topic in each subject. The character values that was tried to be implemented was discipline, responsibility and teamwork.

The lesson plan integrated with character consists of core competition, basic competition and indicator integration between the lesson plan and the character education was designed by connecting the subject and the character values that can be shown in a topic. According to (Hemafitria, 2017) The weakening of the nation's character becomes a serious challenge for the sustainability of Indonesia, especially with the rampant issue of moral decadence in social and state lifeIn building the students' character, the teacher should be the role models in helping students implement the character values. Beside integrating the character education in learning mathematic, the school also provide the assessment book namely "Buku Mathur Jujur" that was given to the students from the third until the sixth grade. This book can helpstudents to learn activeoutside of the school and doing positive activity. Through this book the students are trained to be honest and report their activity every week. This book is also a program by Dinas Pendidikan Kabupaten Klaten to support the PKK (the government program to implement the character education at schools).
The characters building in students is the goal to be achieved in the implementation of character education in this research. There are some problems in integrating the character education like the characteristic of the student, The first problem is the various characteristics of students in one class, so that the teacher still has difficulty in conveying learning with one meeting. The next problem is the lack coordination between the teacher and the parents, so the character values can't optimized. The last problem is about the learning facilities that support integrated learning in character education. The faculties can support involve media, but in the reality the students only learn from the book. The infrastructure is also important to supporting the learning process, but sometimes the schools do not give attention to this problem.

In implementing character building, there are support from some element to reach the learning purpose such as qualified teacher, principal management and students' motivation. The existence of these strengths then the problems faced by teachers can be minimized by optimizing existing strengths.

\section{DISCUSSION}

The character education in learning mathematic can be seen from previous literature such as (Berkowiz, Marvin w et al 2014, Calvert, sandra L et al 2019, Pertiwi, I et al 2017, Kaimuddin 2014, Novitasari, M et al 2019, Jailani j, S. Sugiman, Ezi Apino. 2017, Johar Rahmah et al. 2016, Malikhah, S. 2014.) that explain the character education as an understanding concept in a learning process that implement the character values in learning mathematic. This concept can be executed through the habit and commitment of the all component so the students are able to find their own idea and creativity. This relate to the result study at SD Negeri 2 Sukorejo that already implemented the character education in daily life. The character education at SD Negeri 2 Sukorejo is an innovation to build and implement the character education in daily life, so the students have strong character in facing the development of 21 st century learning. The results show that the implementation of character education has been successful, even though there are some obstacles in its implementation.

This research found several factors in supporting integrating character education in mathematics learning. These supporting factors can support the implementation of the integration of character education in learning. The successful implementation of character education will be in accordance with the target with the support of stakeholders and the commitment of teachers and support from the school. support Stakeholder and support from principals to use strategy to lead the school can greatly affect the formation of student character. This is in line with the findings of (Andriani \& Imron, 2018) which states that teacher commitment is very significant influence on the formation of character education. 
According to Rusman (2009: 75) argues that educational resources such as infrastructure, costs, organization, environment are the keys to educational success, but the main key is the teacher. In addition to supporting factors in this study found obstacles in integrating character education in learning, namely student characteristics, lack of facilities in learning, lack of cooperation between teachers and parents, and lack of adequate school facilities. Various kinds of student characteristics that are not easy for teachers to convey material to students, because not all students can understand at all. The teacher is an important factor in implementing character education in learning. Lack of cooperation between teachers and parents becomes an obstacle because the family environment is a major factor in determining the formation of student character. In this case the teacher and parents have an important role in holding an important position. Hamalik (1992: 100) argues that the role of parents in curriculum development and implementation is related to two things, namely: curriculum development and curriculum implementation. The purpose of this opinion is that parents have a role in planning and implementing student learning in school. Constraints originating from institutions and foundations relating to facilities and infrastructure that support learning are considered inadequate. It is undeniable that current learning requires extensive resources that have actual and non-textual resources.

This research found some factors in supporting the integration of character education in learning mathematic. The character education can be implemented well if it has support from stakeholder, teacher and school. The commitment of stakeholder and principal will give the big influence in building students' character. The commitment of the teacher also gives significance influence towards character building.

The character building is strongly influenced by the family and school environment. Family is the major supporting factor in building student's character. The second component that strengthens the formation of student character is the school environment, this can be seen in SD Negeri 2 Sukorejo namely by the integration of character values in learning. According to (Suarto, 2017), the school and family environment has strong influence towards students' character. In school life, the teacher is the role model where the student can follow their good character. The implementation of the character education should be executed by synergize the institution, learning achievement and teacher as a role model for their student. (Kaimuddin, 2014).

\section{CONCLUSION}

The character education in learning mathematic has a purpose to build students' good character. The character value exists in all topic in every subject. These eighteen character values will have integrated in a learning process. The implementation of character building was supported by the stakeholder. There is someweakness in implementing the character education but it could be helped by the principal management, qualified teacher and students' motivation. The other weakness is come from the lack of infrastructure, the bad coordination between the teacher and the guardians.

\section{REFERENCES}

[1]. G. Eason, B. Noble, and I.N. Sneddon, "On certain integrals of Lipschitz-Hankel type involving products of Bessel functions," Phil. Trans. Roy. Soc. London, vol. A247, pp. 529-551, April 1955. (references)

[2]. J. Clerk Maxwell, A Treatise on Electricity and Magnetism, 3rd ed., vol. 2. Oxford: Clarendon, 1892, pp.68-73.

[3]. I.S. Jacobs and C.P. Bean, "Fine particles, thin films and exchange anisotropy," in Magnetism, vol. III, G.T. Rado and H. Suhl, Eds. New York: Academic, 1963, pp. 271-350.

[4]. K. Elissa, "Title of paper if known," unpublished.

[5]. R. Nicole, "Title of paper with only first word capitalized," J. Name Stand. Abbrev., in press.

[6]. Y. Yorozu, M. Hirano, K. Oka, and Y. Tagawa, "Electron spectroscopy studies on magneto-optical media and plastic substrate interface," IEEE Transl. J. Magn. Japan, vol. 2, pp. 740-741, August 1987 [Digests 9th Annual Conf. Magnetics Japan, p. 301, 1982].

[7]. M. Young, The Technical Writer's Handbook. Mill Valley, CA: University Science, 1989.

[8]. Jailani j, S. Sugiman, Ezi Apino. 2017. 'Implementing the Problem-Based Learning in Order to Improve the Students' HOTS dan Characters. Jurnal Riset Pendidikan Matematika. 4(2) 247-259.

[9]. Johar Rahmah, Tuti Zubaidah, Neni Mariana. 2016. 'Upaya Guru Mengembangkan Karakter Siswa Melalui Pembelajaran Matematika dengan Pendekatan Realistik pad Materi Perkalian. Jurnal Pendidikan Matematika 10(1) 96-110.

[10]. Kaimuddin. 2014. 'Implementasi Pendidikan Karakter dalam kurikulum 2013'. Dinamika Ilmu. 14(1) 47.

[11]. Malikhah, S. 2014. 'Pendidikan Karakter Pada Matapelajaran Ilmu Pengetahuan Sosial'. Jurnal Ilmu Pendidikan. 20(1) 75-85

[12]. Miles, MB, Huberman, M. \& Saldana, J. (2014). Qualitative data analysis: A methods sourcebook. New York, NY: Sage Publication, Inc.

[13]. Novitasari, M, et al (2019). "Promoting Literacy Culture and Character Education to form High-Level Thinking Students in Elementary School'International Journal of Innovative Science and Research Technology. 4(9) 404.

[14]. Pertiwi, I dan Marsigit, M. 2017. 'Implementasi Pendidikan Karakter dalam Pembelajaran Matematika SMP di Kota Yogyakarta'. Jurnal Riset Pendidikan Matematika. 4(2) 153-165.

[15]. Rusman. 2009. Manajemen Kurikulum. Jakarta: PT Raja Grafindo Persada.

[16]. Suarto, E. 2017. Faktor-Faktor Yang Mempengaruhi Dalam Penanaman Pendidikan Karakter Di Sekolah Tingkat Tinggi Pertama Di Kota Padang. Jurnal Manajemen Pendidikan, 2(1): 261-270. 
[17]. Suryadi, A. 2012. Outlook 2025 Pembangunan Pendidikan Indonesia: Menuju Kualitas Yang Berdaya Saing Secara Global (The Indonesian Education Outlook 2025:Toward A Sustainable World Class Quality Level). Jakarta: Badan Penelitian Dan Pengembangan Kementerian Pendidikan Dan Kebudayaan.

[18]. Sutama. 2016. Metode Penelitian Pendidikan Kuantitatif, Kualitatif, PTK dan R\&D. Surakarta: Fairuz Media.

[19]. Sutama. 2017. "Pembelajaran Matematika Bermutu: Menunbuh Kembangkan Peserta Didik Bermartabat". Makalah: Seminar Nasional Pendididkan Matematika: Inovasi Matematika dan Pembelajarannya untuk Indonesia Berkemajuan. Surakarta, 18 Maret 2017.

[20]. Wuryandani W, Bunyamin M S, Dasim B. 2014. 'Pendidikan Karakter Disiplin di Sekolah Dasar'. Cakrawala Pendidikan (2) 286-295. 